\title{
Crystal Structure of the $\mathrm{V}^{\mathrm{V}}$ Dimer $\left[\mathrm{V}_{2} \mathrm{O}_{2}(\mu-\mathrm{O})(\mathrm{dmpp})_{2}\left(\mathrm{OCH}_{3}\right)_{2}\right]$ and Its Equilibrium with the $V^{V}$ Trimer $\left[\mathrm{V}_{3} \mathrm{O}_{3}(\mu-\mathrm{O})_{3}(\mathrm{dmpp})_{3}\left(\mathrm{H}_{2} \mathrm{O}\right)\right]\left(\mathrm{H}_{2} \mathrm{O}\right)_{2}$ in Methanol/Water Solutions
}

\author{
Fernando Avecilla, ${ }^{*[a]}$ Carlos F. G. C. Geraldes, ${ }^{[b]}$ Anjos L. Macedo, ${ }^{[c]}$ and \\ M. Margarida C. A. Castro*[b]
}

Keywords: Vanadium / Pyridinone complexes / NMR spectroscopy / X-ray crystallography

The behaviour of the cyclic trimeric $\mathrm{V}^{\mathrm{V}}$ complex $\left[\mathrm{V}_{3} \mathrm{O}_{3}(\mu-\right.$ $\left.\mathrm{O})_{3}(\mathrm{dmpp})_{3}\left(\mathrm{H}_{2} \mathrm{O}\right)\right]\left(\mathrm{H}_{2} \mathrm{O}\right)_{2}, \mathrm{~V}_{3} \mathrm{~L}_{3},(\mathrm{~L}=\mathrm{Hdmpp}=3$-hydroxy-1,2dimethyl-4-pyridinone) was studied in methanol and methanol/water solutions by using ${ }^{51} \mathrm{~V}$ and $1 \mathrm{D}$ - and $2 \mathrm{D}{ }^{1} \mathrm{H}$ NMR spectroscopy. Red crystals, isolated from a highly concentrated methanol solution of the trimeric complex, were analysed by X-ray crystallography. The solid-state structure of the compound showed the presence of a new dinuclear $\mathrm{V}^{\mathrm{V}}$ cluster and allowed for its formulation as a $\left[\mathrm{V}_{2} \mathrm{O}_{2}(\mu-\mathrm{O})\right.$ $\left.(\mathrm{dmpp})_{2}\left(\mathrm{OCH}_{3}\right)_{2}\right]$ complex, $\mathrm{V}_{2} \mathrm{Y}_{2} \mathrm{~L}_{2}\left(\mathrm{Y}=\mathrm{OCH}_{3}\right)$. This complex crystallises in the monoclinic system: $P 2{ }_{1} / c, a=8.4573(11) \AA$, $b=15.034(2) \AA$ and $c=15.849(2) \AA, \beta=105.300(2)^{\circ}, V=$ $1943,7(4) \AA^{3}, Z=2$, and $R_{1}\left(w R_{2}\right)=0.0492(0.1706)$. The trimer $\mathrm{V}_{3} \mathrm{~L}_{3}$ complex dissolved in a dry methanol solution fully decomposes, as shown by the ${ }^{51} \mathrm{~V}$ NMR signals at $-388,-450$ and $-551 \mathrm{ppm}$, which are assigned to a monomer complex $\left[\mathrm{VO}(\mathrm{OMe})(\mathrm{dmpp})_{2}\right]\left(\mathrm{VYL}_{2}\right)$, the dimer $\mathrm{V}_{2} \mathrm{Y}_{2} \mathrm{~L}_{2}$ and the monomethyl ester of monovanadate, $\mathrm{V}_{1} \mathrm{Y}\left(\mathrm{V}_{1}=\right.$ monovanadate; $\mathrm{Y}$ $\left.=\mathrm{OCH}_{3}\right)$, respectively. In methanol/water solutions, a new ${ }^{51} \mathrm{~V}$ NMR signal appears at $\delta=-492 \mathrm{ppm}$, which is assigned to the $\left[\mathrm{VO}_{2}(\mathrm{dmpp})\left(\mathrm{H}_{2} \mathrm{O}\right)_{2}\right](\mathrm{VL})$ complex. When the percentage of water in the mixture increases, the relative intensities of the $\mathrm{V}_{2} \mathrm{Y}_{2} \mathrm{~L}_{2}$ and $\mathrm{V}_{1} \mathrm{Y}$ signals decrease sharply, and a broad signal at -488 ppm appears, corresponding to the original $\mathrm{V}^{\mathrm{V}}$ trimer complex, which is the only species present in $94 \%$ water. A temperature-dependent ${ }^{1} \mathrm{H}$ NMR study of a $\mathrm{CD}_{3} \mathrm{OD}$ solution of $\mathrm{V}_{3} \mathrm{~L}_{3}$ confirmed the presence, at room temperature, of the dinuclear $\mathrm{V}_{2} \mathrm{~L}_{2}$ complex and the $\mathrm{VL}_{2}$ species. At temperatures below $0{ }^{\circ} \mathrm{C}$ down to $-50{ }^{\circ} \mathrm{C}$, the appearance of new signals reflects the presence of isomers for the $V_{2} Y_{2} L_{2}$ and $\mathrm{VYL}_{2}$ species with different stabilities and symmetries. 2D ${ }^{1} \mathrm{H}$ homonuclear NMR exchange experiments (EXSY) allowed us to establish the isomeric equilibria that take place in solution, and indicates intramolecular exchange between the two ligands of the major isomer of $\mathrm{VYL}_{2}$ and intermolecular exchange between the major and minor isomers of species of different nuclearity, $\mathrm{V}_{2} \mathrm{Y}_{2} \mathrm{~L}_{2}$ and $\mathrm{VYL}_{2}$. However, no evidence was found for intermolecular exchange between the major isomers and between the minor isomers of species of different nuclearity or between isomers of species of the same nuclearity.

() Wiley-VCH Verlag GmbH \& Co. KGaA, 69451 Weinheim, Germany, 2006)

\section{Introduction}

Vanadium is an essential biological trace element of the utmost importance. $^{[1,2]}$ It is present in some biological systems in high concentrations, where it seems to have a relevant role, such as in the Amanita muscaria mushroom as the amavadin complex ${ }^{[3]}$ and in some ascideas in the form of tunichromes. ${ }^{[4]}$ Vanadium is the cofactor of some enzymes, like the vanadium-dependent haloperoxidases in al-

[a] Departamento de Química Fundamental, Universidade da Coruña,

Campus de A Zapateira s/n, 15071, A Coruña, Spain

E-mail: avecil@udc.es

[b] Departamento de Bioquímica, Centro de Espectroscopia RMN e Centro de Neurociências e Biologia Celular, Faculdade de Ciências e Tecnologia, Universidade de Coimbra,

Apartado 3126, 3001-401 Coimbra, Portugal E-mail: gcastro@ci.uc.pt

[c] REQUIMTE, C.Q.F.B., Departamento de Química, Faculdade de Ciências e Tecnologia, Universidade Nova de Lisboa, 2829-516 Caparica, Portugal gae and lichens ${ }^{[5]}$ and the vanadium-nitrogenases in some bacteria. ${ }^{[6]}$ It also interferes with the activity of certain enzymes, in particular those involved in phosphorylations, ${ }^{[7]}$ where it acts as a phosphate analogue, and it is responsible for many physiological and metabolic effects observed in different organisms, where it is essential at low concentrations although toxic at concentrations higher than $1 \mathrm{~mm}^{\left[{ }^{[8]}\right.}$ Vanadium in biological systems mainly occurs as the anionic vanadate $\left(\mathrm{V}^{\mathrm{V}}\right)$, which is isostructural to phosphate, or the cationic vanadyl $\left(\mathrm{V}^{\mathrm{IV}}\right)$, depending on the redox properties of the medium. ${ }^{[8]}$ The insulin-mimetic properties of inorganic vanadate and vanadyl, ${ }^{[9]}$ as well as of some $\mathrm{V}^{\mathrm{IV}}$ and $\mathrm{V}^{\mathrm{V}}$ complexes, ${ }^{[10]}$ have stimulated the search for a vanadium complex that can be used as an effective oral substitute for insulin. The well-recognised biological importance of vanadium has attracted much interest for its coordination and redox chemistry both in the $\mathrm{V}^{\mathrm{IV}}$ and $\mathrm{V}^{\mathrm{V}}$ oxidation states and both in the solid state and in solution. The interest extends to the modeling of the interaction of vanadium 
with living systems, with particular focus on the structural and functional biological activity of this element.

The aqueous chemistry of vanadium(V) is very complex. Hydrolysis, redox and oligomerization reactions can occur in solution, resulting in different species, depending on the $\mathrm{pH}$, ionic strength and total vanadium concentration in the medium, ${ }^{[1]}$ which together determine the coordination properties of vanadium(V). The structure and reactivity of vanadate in other solvents, in particular alcohols, have been largely studied. ${ }^{[12]}$ Vanadium complexes with different geometries and coordination modes containing $\mathrm{O}$ and/or $\mathrm{N}$ and/or $\mathrm{S}$ as donor atoms in their structures ${ }^{[6 \mathrm{~b}, 11,13]}$ have been useful model compounds to understand the coordination chemistry of vanadium in living systems. In particular, the solid-state structures of $\mathrm{V}^{\mathrm{IV}}$ and $\mathrm{V}^{\mathrm{V}}$ compounds with ligands from the class of pyrones and pyridinones (with one ketonic and one enolic group as donor atoms) have been determined by X-ray crystallography ${ }^{[14 a, 15]}$ and EXAFS. ${ }^{[16]}$ The speciation of these vanadium compounds in solution has been extensively studied by using potentiomety, UV/ Vis, ${ }^{51} \mathrm{~V}$ and ${ }^{1} \mathrm{H}$ NMR and EPR spectroscopy. ${ }^{[14 \mathrm{a}, 16-18]}$ Compound bis(maltolato)oxidovanadium(IV) [BMOV, $\mathrm{VO}(\mathrm{ma})_{2}, \mathrm{ma}=$ maltolate $]$ was the first example to be used as an insulin-mimetic complex, ${ }^{[14,19]}$ and phase 1 clinical trials in humans have been completed on bis(ethylmaltolato)oxidovanadium(IV) (BEOV). ${ }^{[20]}$ Several other oxovanadium(IV) complexes have also been reported to exhibit insulin-mimetic properties in vivo. ${ }^{[21]}$ The compound bis(3hydroxy-1,2-dimethyl-4-pyridinone)oxidovanadium(IV), $\mathrm{VO}(\mathrm{dmpp})_{2}$ (see Scheme 1 for the structure of the ligand Hdmpp), as well as the ternary systems formed with low molecular mass components of blood serum have also been studied in aqueous solution under anaerobic and aerobic conditions. $^{[17,18]}$ At physiological $\mathrm{pH}, \mathrm{VO}(\mathrm{dmpp})_{2}$ showed low toxicity in erythrocyte suspensions ${ }^{[22]}$ and promising in vitro insulin-like properties in fibroblast cell lines ${ }^{[23 a]}$ and in rat adipocytes. ${ }^{[23 \mathrm{~b}]}$<smiles></smiles>

Scheme 1.

The interaction of vanadate with the ligand Hdmpp in aqueous solution has been extensively studied by us. ${ }^{[18]} \mathrm{A}$ new trinuclear oxovanadium(V) complex was isolated from aqueous solution at a $\mathrm{pH}$ of 4-5 and was characterised in the solid state by $\mathrm{X}$-ray crystallography as $\left[\mathrm{V}_{3} \mathrm{O}_{3}(\mu-\mathrm{O})_{3}\right.$ $\left.(\mathrm{dmpp})_{3}\left(\mathrm{H}_{2} \mathrm{O}\right)\right]\left(\mathrm{H}_{2} \mathrm{O}\right)_{2}$ that contains a cyclic $\mathrm{V}^{\mathrm{V}}$ cluster and in aqueous solution by mass spectrometry and ${ }^{51} \mathrm{~V}$ and ${ }^{1} \mathrm{H}$ NMR spectroscopy. ${ }^{[24]}$ In this work, we report on the behaviour of this trinuclear $\mathrm{V}^{\mathrm{V}}$ compound in methanol and methanol/water solutions investigated by ${ }^{51} \mathrm{~V}$ NMR spectroscopy and $1 \mathrm{D}$ and $2 \mathrm{D}{ }^{1} \mathrm{H}$ NMR spectroscopy. The red crystals that formed from a highly concentrated $\mathrm{CD}_{3} \mathrm{OD}$ solution of the $\mathrm{V}^{\mathrm{V}}$ trimer were structurally analysed, and the X-ray crystallographic data obtained indicated the formation of a new dinuclear $\mathrm{V}^{\mathrm{V}}$ compound $\left[\mathrm{V}_{2} \mathrm{O}_{2}(\mu\right.$ $\left.\mathrm{O})(\mathrm{dmpp})_{2}\left(\mathrm{OCH}_{3}\right)_{2}\right]$.

\section{Results and Discussion}

\section{X-ray Structure}

The X-ray structure obtained for the crystalline $\left[\mathrm{V}_{2} \mathrm{O}_{2}(\mu-\right.$ $\left.\mathrm{O})(\mathrm{dmpp})_{2}\left(\mathrm{OCH}_{3}\right)_{2}\right]$ complex $\left(\mathrm{V}_{2} \mathrm{Y}_{2} \mathrm{~L}_{2}\right)$ is shown in Figure 1 with the atomic numbering scheme, and the corresponding bond lengths and angles are listed in Table 1. It consists of a dinuclear oxovanadium(V) complex with two anionic dmpp ligands, one oxygen atom bridge and two methoxy groups, each coordinated to one vanadium atom. The oxygen atom bridge links the two vanadium atoms, each one of which is also coordinated to one oxo group. Both V1 and V2 atoms adopt a distorted six-coordinate octahedral geometry (Figure 2). The V1 coordination sphere is composed of an enolate oxygen atom [V1-O6 =

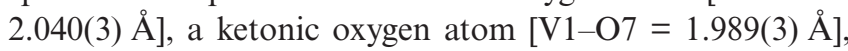
a deprotonated alkoxide oxygen atom of a methoxy group $[\mathrm{V} 1-\mathrm{O} 1 \mathrm{M}=1.787(4) \AA]$, a terminal oxo atom [V1-O1 = $1.594(3) \AA]$ and a second oxo atom [V1-O4 = 1.824(3) $\mathrm{A}]$ that forms a strong bridge to V2 [V2-O4 $=1.804(3) \AA]$. The remainder of the $\mathrm{V} 2$ coordination sphere is completed by an enolate oxygen $[\mathrm{V} 2-\mathrm{O} 3=2.060(3) \AA]$, a ketonic oxygen atom [V2-O5 = 1.972(3) $\AA$ ], an alkoxide oxygen atom of the other methoxy ligand [V2-O2M = 1.783(3) $\AA$ ] and a

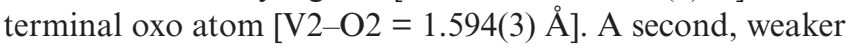

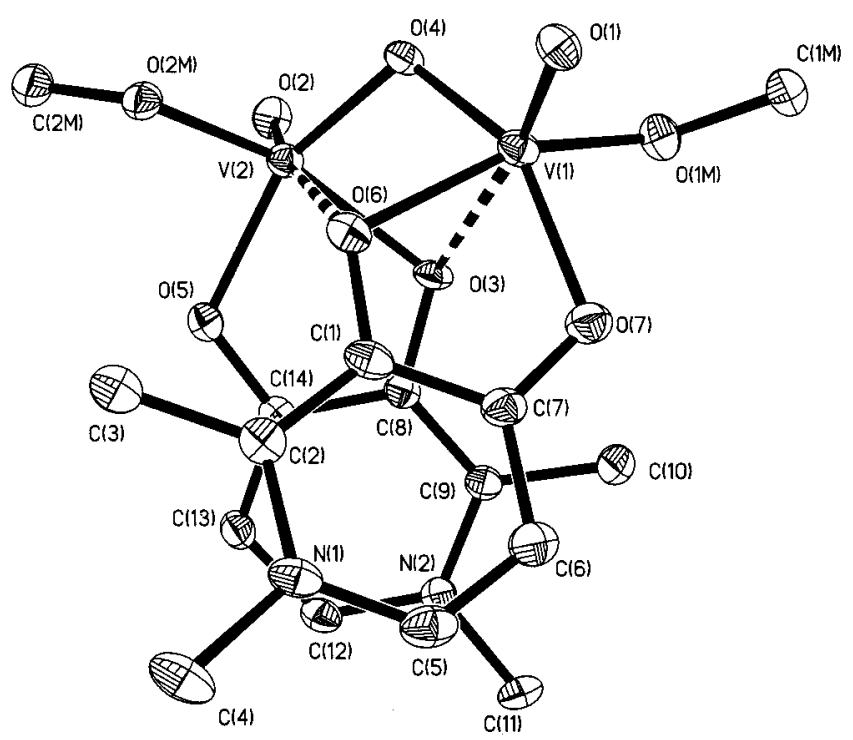

Figure 1. X-ray crystal structure of the complex $\left[\mathrm{V}_{2} \mathrm{O}_{2}(\mu-\mathrm{O})\right.$ $(\mathrm{dmpp})_{2}\left(\mathrm{OCH}_{3}\right)_{2}$ ] showing the atomic numbering scheme. Hydrogen atoms have been omitted for simplicity. The ORTEP plot is at the $30 \%$ probability level. 
bridge between V1 and V2 is formed by an enolate oxygen (O3) of the ligand coordinated to V2 (see Table 1) and an enolate oxygen $(\mathrm{O} 6)$ of the ligand coordinated to V1. The

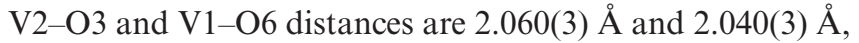
respectively, as compared with the V1-O3 and V2-O6 bond lengths of 2.464(3) $\AA$ and 2.589(3) $\AA$, respectively. The vanadium atom V1 is located at $0.33697 \AA$ from the axial plane defined by $\mathrm{O} 4, \mathrm{O} 6, \mathrm{O} 7$ and $\mathrm{O} 1 \mathrm{M}$, and the vanadium atom V2 is $0.4010 \AA$ from the basal plane defined by O3, $\mathrm{O} 4, \mathrm{O} 5$ and $\mathrm{O} 2 \mathrm{M}$ (Figure 2). Both vanadium atoms have a strong $\mathrm{V}=\mathrm{O}$ bond, as the values of the V1-O1 and $\mathrm{V} 2-\mathrm{O} 2$ distances are compatible with those found in other similar structures. ${ }^{[25]}$ All bond lengths are in the range of the values

Table 1. Selected bond lengths $[\AA]$ and angles $\left[{ }^{\circ}\right]$ for $\left[\mathrm{V}_{2} \mathrm{O}_{2}(\mu-\right.$ $\left.\mathrm{O})(\mathrm{dmpp})_{2}\left(\mathrm{OCH}_{3}\right)_{2}\right]$ with estimated standard deviations in parentheses. M indicates the methoxy oxygen atoms.

\begin{tabular}{llll}
\hline Bond lengths & & & \\
\hline $\mathrm{V}(1)-\mathrm{O}(1)$ & $1.594(3)$ & $\mathrm{V}(2)-\mathrm{O}(2)$ & $1.594(3)$ \\
$\mathrm{V}(1)-\mathrm{O}(1 \mathrm{M})$ & $1.787(4)$ & $\mathrm{V}(2)-\mathrm{O}(2 \mathrm{M})$ & $1.783(3)$ \\
$\mathrm{V}(1)-\mathrm{O}(3)$ & $2.464(3)$ & $\mathrm{V}(2)-\mathrm{O}(3)$ & $2.060(3)$ \\
$\mathrm{V}(1)-\mathrm{O}(4)$ & $1.824(3)$ & $\mathrm{V}(2)-\mathrm{O}(4)$ & $1.804(3)$ \\
$\mathrm{V}(1)-\mathrm{O}(6)$ & $2.040(3)$ & $\mathrm{V}(2)-\mathrm{O}(5)$ & $1.972(3)$ \\
$\mathrm{V}(1)-\mathrm{O}(7)$ & $1.989(3)$ & $\mathrm{V}(2)-\mathrm{O}(6)$ & $2.589(3)$ \\
\hline
\end{tabular}

Bond angles

$\mathrm{O}(1)-\mathrm{V}(1)-\mathrm{O}(1 \mathrm{M}) \quad 99.94(17) \quad \mathrm{O}(2)-\mathrm{V}(2)-\mathrm{O}(2 \mathrm{M}) \quad 101.51(17)$

$\mathrm{O}(1)-\mathrm{V}(1)-\mathrm{O}(4) \quad 104.13(17)$

$\mathrm{O}(1 \mathrm{M})-\mathrm{V}(1)-\mathrm{O}(4) \quad 103.30(16)$

$\mathrm{O}(1)-\mathrm{V}(1)-\mathrm{O}(7) \quad 101.56(17)$

$\mathrm{O}(1 \mathrm{M})-\mathrm{V}(1)-\mathrm{O}(7) \quad 86.57(16)$

$\mathrm{O}(4)-\mathrm{V}(1)-\mathrm{O}(7) \quad 150.29(15)$

$\mathrm{O}(1)-\mathrm{V}(1)-\mathrm{O}(6) \quad 99.11(16)$

$\mathrm{O}(1 \mathrm{M})-\mathrm{V}(1)-\mathrm{O}(6) \quad 158.03(16)$

$\mathrm{O}(4)-\mathrm{V}(1)-\mathrm{O}(6) \quad 82.46(14)$

$\mathrm{O}(7)-\mathrm{V}(1)-\mathrm{O}(6) \quad 78.95(14)$

$\mathrm{O}(1)-\mathrm{V}(1)-\mathrm{O}(3) \quad 171.68(16)$

$\mathrm{O}(1 \mathrm{M})-\mathrm{V}(1)-\mathrm{O}(3) \quad 87.04(14)$

$\mathrm{O}(4)-\mathrm{V}(1)-\mathrm{O}(3) \quad 69.59(12)$

$\mathrm{O}(7)-\mathrm{V}(1)-\mathrm{O}(3) \quad 83.25(13)$

$\mathrm{O}(6)-\mathrm{V}(1)-\mathrm{O}(3) \quad 74.99(12)$

$\mathrm{O}(2)-\mathrm{V}(2)-\mathrm{O}(4) \quad 104.61(17)$

$\mathrm{O}(2 \mathrm{M})-\mathrm{V}(2)-\mathrm{O}(4) \quad 102.85(15)$

$\mathrm{O}(2)-\mathrm{V}(2)-\mathrm{O}(5) \quad 100.86(17)$

$\mathrm{O}(2 \mathrm{M})-\mathrm{V}(2)-\mathrm{O}(5) \quad 87.46(15)$

$\mathrm{O}(4)-\mathrm{V}(2)-\mathrm{O}(5) \quad 149.83(15)$

$\mathrm{O}(2)-\mathrm{V}(2)-\mathrm{O}(3) \quad 101.90(16)$

$\mathrm{O}(2 \mathrm{M})-\mathrm{V}(2)-\mathrm{O}(3) \quad 154.64(15)$

$\mathrm{O}(4)-\mathrm{V}(2)-\mathrm{O}(3) \quad 80.46(14)$

$\mathrm{O}(5)-\mathrm{V}(2)-\mathrm{O}(3) \quad 78.69(13)$

$\mathrm{O}(2)-\mathrm{V}(2)-\mathrm{O}(6) \quad 171.03(15)$

$\mathrm{O}(2 \mathrm{M})-\mathrm{V}(2)-\mathrm{O}(6) \quad 85.82(14)$

$\mathrm{O}(4)-\mathrm{V}(2)-\mathrm{O}(6) \quad 68.37(12)$

$\mathrm{O}(5)-\mathrm{V}(2)-\mathrm{O}(6) \quad 84.49(13)$

$\mathrm{O}(3)-\mathrm{V}(2)-\mathrm{O}(6) \quad 71.85(12)$

$\mathrm{V}(2)-\mathrm{O}(3)-\mathrm{V}(1) \quad 81.85(11)$

$\mathrm{V}(2)-\mathrm{O}(4)-\mathrm{V}(1) \quad 110.33(16)$

$\mathrm{V}(1)-\mathrm{O}(6)-\mathrm{V}(2) \quad 79.12(11)$

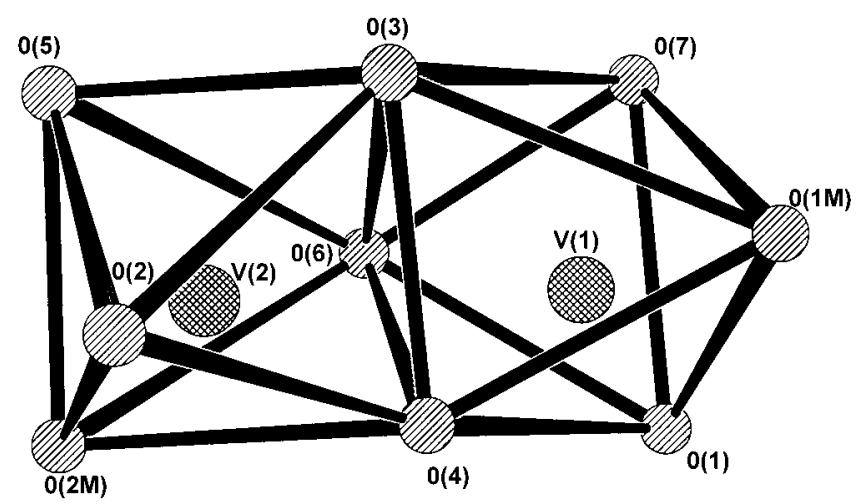

Figure 2. Coordination polyhedra in the crystal structure of the vanadium cluster in the dimeric species $\left[\mathrm{V}_{2} \mathrm{O}_{2}(\mu-\mathrm{O})(\mathrm{dmpp})_{2^{-}}\right.$ $\left.\left(\mathrm{OCH}_{3}\right)_{2}\right]$. reported in the literature for other known polynuclear vana$\operatorname{dium}(\mathrm{V})$ complexes. ${ }^{[14 a, 15,26]}$

The oxido and methoxido ligands of the $\mathrm{V}_{2} \mathrm{Y}_{2} \mathrm{~L}_{2}$ dimer, which exert a strong trans influence, are cis to one another. The preference of these ligands for a cis configuration in such complexes has been demonstrated in $\mathrm{VO}(\mathrm{OMe})(\mathrm{L})$ compounds where $\mathrm{L}$ represents the tetradentate Schiff bases $\quad N, N^{\prime}$-2,2-dimethyltrimethylenebis[salicylidenaminato(2-)] (salnptn) and $N, N^{\prime}$-ethylenebis[salicylideneaminato(2-)] (salen) $\}.{ }^{[27]}$ In these complexes, a cis-VO(OMe) arrangement was allowed by forcing the normally planar tetradentate Schiff base ligands into three equatorial and one axial coordination positions. The oxido and methoxido ligands are also cis to one another in the cis- $\mathrm{VO}(\mathrm{OMe})$ $(\mathrm{ma})_{2}$ complex, which results from aerobic oxidation of the bis(maltolato)oxidovanadium(IV) complex $\left[\mathrm{VO}(\mathrm{ma})_{2}\right.$, BOMV] in methanol. ${ }^{[14 a, 15 a]}$

The $\mathrm{V}_{2} \mathrm{Y}_{2} \mathrm{~L}_{2}$ dimer complex has an enolic dmpp oxygen atom (O3 in V1) that is trans and four dmpp oxygen atoms (enolic $\mathrm{O} 6$ and ketonic $\mathrm{O} 7$ in V1, and enolic $\mathrm{O} 3$ and ketonic $\mathrm{O} 5$ in $\mathrm{V} 2$ ) that are cis relative to the strong $\mathrm{V}=\mathrm{O}$ bond in each vanadium atom. ${ }^{[14 a, 15 a]}$ The dmpp oxygen atoms belonging to the enolic groups are deprotonated (O3 and O6). The trans position is destabilised with respect to the other positions, as shown by the length of the V1-O3 and V2-O6 bonds in the $\mathrm{V}_{2} \mathrm{Y}_{2} \mathrm{~L}_{2}$ species, in a manner similar to that in other dimeric and monomeric compounds. ${ }^{[28]}$ The dmpp ligand has a strong preference for meridional coordination, except when a methoxy group or a water molecule competes with it for the cis position relative to the oxo group.

The dinuclear complex contains the $\mathrm{V}_{2} \mathrm{O}_{3}$ framework, ${ }^{[15 \mathrm{~b}]}$ which exhibits one bridging oxygen atom (O4) and the formal enolic oxygen atoms (O3 and O6) of the two dmpp groups. From the X-ray results one could not unambiguously distinguish between a keto-O5 and an enolate-O3 structure for this bifunctional binding group, as the $\mathrm{C}-\mathrm{O}$ bond lengths to the formal keto and enolate oxygen atoms in the C-O-V-O-C chain are almost the same $\{$ e.g. C8-O3

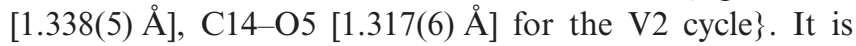
possible that the $\pi$ electron cloud is delocalised over all the atoms that form each $\mathrm{C}-\mathrm{O}-\mathrm{V}-\mathrm{O}-\mathrm{C}$ cycle, giving an intermediate character to all the formal ketonic and enolic oxygen atoms of each dmpp molecule. ${ }^{[24]}$ As expected, the doubly bridging (O3 and O6) dmpp atoms have $\mathrm{V}-\mathrm{O}$ bond $[2.464(3)$ and 2.060(3) $\AA$ for $(\mathrm{O} 3), 2.040(3) \AA$ and 2.589(3) $\AA$ for (O6)] that are longer than the $\mathrm{V}-\mathrm{O}$ bond for the bridging oxygen atom (O4) [1.824(3) and 1.804(3) $\AA$ ]. The V2-O6 distance [2.589(3) $\AA$ ] is even longer than the V1-O3 distance. The average value of the $\mathrm{V}-\mathrm{O}-\mathrm{V}$ bond lengths is 1.81(2), which is similar to that obtained for other polynuclear vanadium compounds. ${ }^{[29]}$ In the $\mathrm{V}_{2} \mathrm{O}_{3}$ framework, the bond angle V1-O4-V2 $\left[110.35(16)^{\circ}\right]$ is very different from the bond angles V1-O3-V2 [81.81(11) ${ }^{\circ}$ and V1-O6-V2 $\left[79.12(11)^{\circ}\right]$. This is in agreement with the results published for the trimeric species $\left[\mathrm{V}_{3} \mathrm{O}_{3}(\mu-\mathrm{O})_{3^{-}}\right.$ $\left.(\mathrm{dmpp})_{3}\left(\mathrm{H}_{2} \mathrm{O}\right)\right]\left(\mathrm{H}_{2} \mathrm{O}\right)_{2} \cdot{ }^{[24]}$

Figure 3 shows an upper view of the complex along the pseudo- $C_{2}$ axis, which passes along the oxygen atom $\mathrm{O} 4$. 


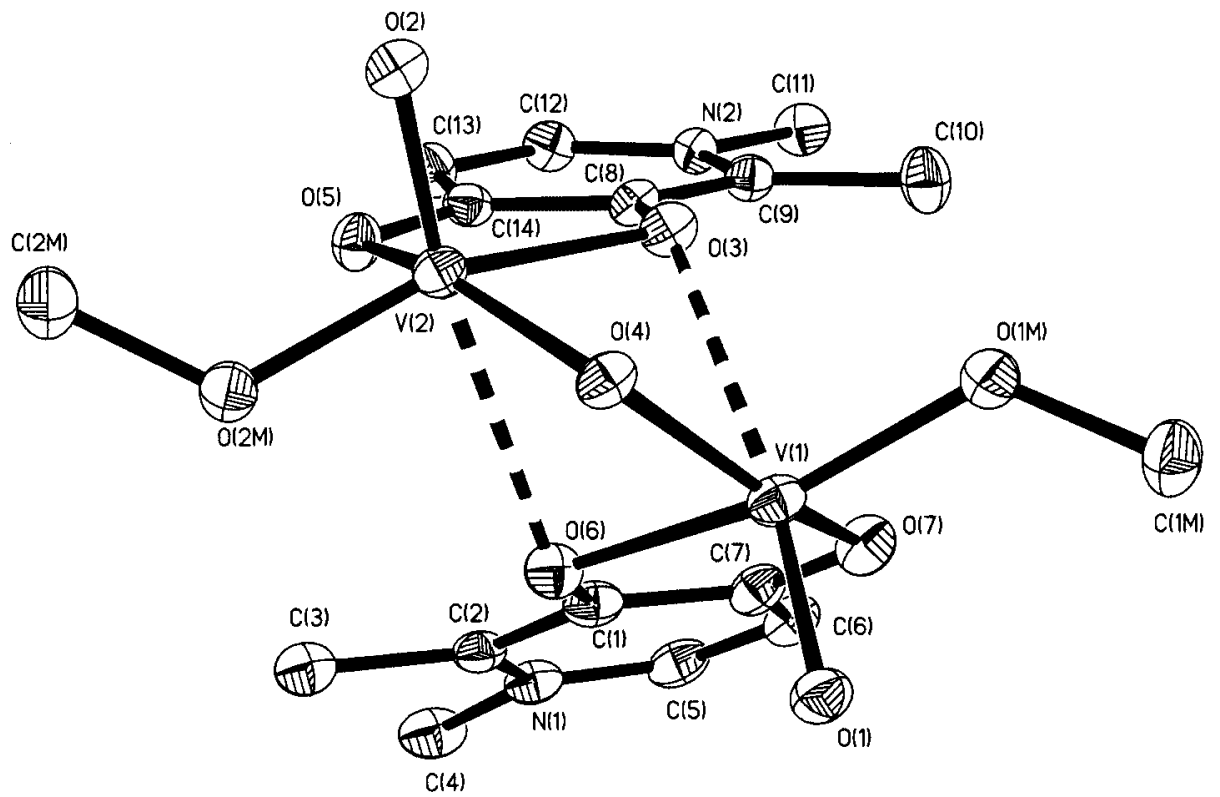

Figure 3. Upper view of the complex $\left[\mathrm{V}_{2} \mathrm{O}_{2}(\mu-\mathrm{O})(\mathrm{dmpp})_{2}\left(\mathrm{OCH}_{3}\right)_{2}\right]$. Hydrogen atoms have been omitted for simplicity. The ORTEP plot is at the $30 \%$ probability level.

This view clearly illustrates the pseudo- $C_{2}$ symmetry of the complex. Each of the two methoxy groups is coordinated to each of the two vanadium atoms. The angle between the planes of the two dmpp ligands is $34.6^{\circ}$. In this view, it is easy to foresee that a dynamic equilibrium between different isomers can occur in solution.

\section{Solution Studies}

\section{${ }^{51}$ V NMR Spectroscopic Studies}

The behaviour of the cyclic $\mathrm{V}^{\mathrm{V}}$ trimer compound $\left[\mathrm{V}_{3} \mathrm{O}_{3}(\mu-\mathrm{O})_{3}(\mathrm{dmpp})_{3}\left(\mathrm{H}_{2} \mathrm{O}\right)\right]\left(\mathrm{H}_{2} \mathrm{O}\right)_{2},\left(\mathrm{~V}_{3} \mathrm{~L}_{3}\right)^{[24]}$ was studied as a function of solvent composition by ${ }^{51} \mathrm{~V}$ NMR spectroscopy. Dissolution of black crystals of $\mathrm{V}_{3} \mathrm{~L}_{3}$ in dry methanol gives a ${ }^{51} \mathrm{~V}$ NMR spectrum that shows four signals with different intensities at -386 (shoulder), $-388,-450$ and $-551 \mathrm{ppm}$ (Figure 4A), which indicates the presence of four different vanadium(V) species in solution. The signal at $-551 \mathrm{ppm}$ corresponds to the monomethyl ester of vanadate $\mathrm{V}_{1} \mathrm{Y}\left(\mathrm{V}_{1}=\right.$ monovanadate; $\left.\mathrm{Y}=\mathrm{OCH}_{3}\right),{ }^{[12 \mathrm{c}]}$ which was previously detected as one of the products resulting from the aerobic oxidation in methanol solution of $\mathrm{VO}(\mathrm{ma})_{2}$ to $\left[\mathrm{VO}\left(\mathrm{OCH}_{3}\right)(\mathrm{ma})_{2}\right]$ and was described as $\left[\mathrm{VO}\left(\mathrm{OCH}_{3}\right)\right]^{2+} \cdot{ }^{115 \mathrm{a}]}$ The signal at $-450 \mathrm{ppm}$, with the highest intensity, was assigned to the dimer $\mathrm{V}^{\mathrm{V}}$ complex $\mathrm{V}_{2} \mathrm{Y}_{2} \mathrm{~L}_{2}$. This assignment is corroborated by the observation of ${ }^{51} \mathrm{~V}$ high frequency shifts of the signals for the dimer with respect to those of the monomer in other systems, such as the oxovanadium alkoxides $\mathrm{VO}(\mathrm{OR})_{3}$ or vanadate complexes of hydroxy acids such as glycerate or lactate. ${ }^{[30]}$

In a highly concentrated methanol solution, this compound precipitates as red crystals, which were analysed by $\mathrm{X}$-ray crystallography. The crystal structure is presented in this work. The signal at $-388 \mathrm{ppm}$ was assigned to cis$\left[\mathrm{VO}\left(\mathrm{OCH}_{3}\right)(\mathrm{dmpp})_{2}\right] \quad\left(\mathrm{VYL}_{2}\right)$ containing one methoxy
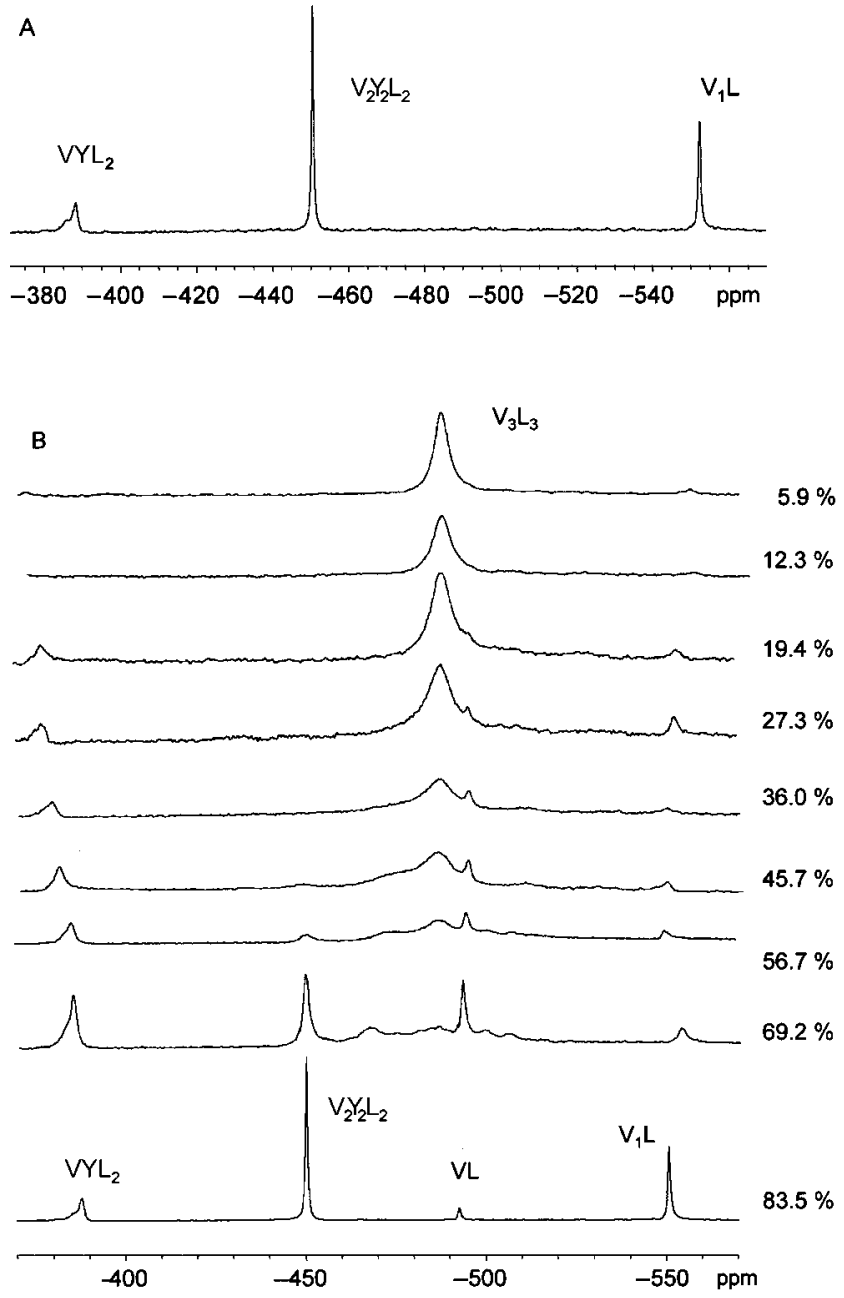

Figure 4. ${ }^{51} \mathrm{~V}$ NMR spectra of solutions of the crystalline $\mathrm{V}^{\mathrm{V}}$ compound $\left[\mathrm{V}_{3} \mathrm{O}_{6}(\mathrm{dmpp})_{3}\left(\mathrm{H}_{2} \mathrm{O}\right)\right] \cdot\left(\mathrm{H}_{2} \mathrm{O}\right)_{2}$ obtained at $131.404 \mathrm{MHz}$ and at $22.0 \pm 0.5^{\circ} \mathrm{C}$ in (A) dry $\mathrm{CH}_{3} \mathrm{OH}$; (B) $\mathrm{CH}_{3} \mathrm{OH} / \mathrm{H}_{2} \mathrm{O}$ mixtures, at $\mathrm{pH} \approx 4$ and different $\mathrm{CH}_{3} \mathrm{OH} / \mathrm{H}_{2} \mathrm{O}$ mol ratios. The $\mathrm{CH}_{3} \mathrm{OH}$ mol $\%$ is shown in the figure. 
group, analogous to the bis(maltolato) complex $\left[\mathrm{VO}\left(\mathrm{OCH}_{3}\right)(\mathrm{ma})_{2}\right],{ }^{[14 a, 15 a]}$ and its shoulder at $-386 \mathrm{ppm}$ to the corresponding trans isomer.

The ${ }^{51} \mathrm{~V}$ NMR spectra of the trimer $\mathrm{V}_{3} \mathrm{~L}_{3}$ dissolved in methanol/water solutions with different percentages of the two solvents dramatically change with the solvent composition, as shown in Figure 4B. In a solution where the mol fraction of $\mathrm{CH}_{3} \mathrm{OH}$ is $83.5 \%$, a new signal appears at $\delta=$ $-492 \mathrm{ppm}$, in addition to those already present. This signal, which is absent in pure methanol and only appears when water is present in solution, was assigned to the $\left[\mathrm{VO}_{2}(\mathrm{dmpp})\left(\mathrm{H}_{2} \mathrm{O}\right)_{2}\right](\mathrm{VL})$ complex with no methoxy group in its structure, which, at $\mathrm{pH} \approx 4$ appears at $-492 \mathrm{ppm}$, as previously reported. ${ }^{[18]}$ The relative intensities of the $\mathrm{V}_{2} \mathrm{Y}_{2} \mathrm{~L}_{2}$ and $\mathrm{V}_{1} \mathrm{Y}$ signals decrease sharply when the percentage of water in the solution increases. The first signal completely disappears at $36.0 \% \mathrm{CH}_{3} \mathrm{OH}$ and the second one at $12.3 \% \mathrm{CH}_{3} \mathrm{OH}$. The signals for the $\mathrm{VL}$ and $\mathrm{VYL}_{2}$ species disappear at $12.3 \% \mathrm{CH}_{3} \mathrm{OH}$. Furthermore, the $\mathrm{VYL}_{2}$ signals gradually shift with increasing water content, up to a value of $-376 \mathrm{ppm}$, reflecting the formation of the $\left[\mathrm{VO}(\mathrm{OH})(\mathrm{dmpp})_{2}\right]$ complex, which dominates in water solution at $\mathrm{pH} \approx 4 .{ }^{[18]} \mathrm{In}$ addition, at $69.2 \% \mathrm{CH}_{3} \mathrm{OH}$, a broad signal appears at $-488 \mathrm{ppm}$. Its intensity increases with the percentage of water, and when water is present at $94.1 \%$, it is the only signal observed in the ${ }^{51} \mathrm{~V}$ NMR spectrum (Figure 4B). This signal corresponds to the original $\mathrm{V}^{\mathrm{V}}$ trimer complex $\mathrm{V}_{3} \mathrm{~L}_{3}$, whose ${ }^{51} \mathrm{~V}$ NMR signal in aqueous solution at $\mathrm{pH} \approx 4$ has already been reported. ${ }^{[24]}$ This was confirmed by slowly evaporating the methanol from a water/methanol solution of the $\mathrm{V}^{\mathrm{V}}$ trimer at room temperature, which leads to an aqueous solution that gives a ${ }^{51} \mathrm{~V}$ NMR spectrum consisting of the same single, broad signal at $-488 \mathrm{ppm}$. After some time, black crystals were isolated from the solution, and characterisation of their structure by $\mathrm{X}$-ray crystallography confirmed that these are indeed crystals of the $\mathrm{V}^{\mathrm{V}}$ trimer $\mathrm{V}_{3} \mathrm{~L}_{3}$ compound, whose structure had been previously reported. ${ }^{[24]}$

\section{${ }^{1}$ H NMR Spectroscopic Studies}

${ }^{1} \mathrm{H}$ NMR spectra of solutions of the $\mathrm{V}^{\mathrm{V}}$ trimer, $\left[\mathrm{V}_{3} \mathrm{O}_{3}(\mu-\right.$ $\left.\mathrm{O})_{3}(\mathrm{dmpp})_{3}\left(\mathrm{H}_{2} \mathrm{O}\right)\right]\left(\mathrm{H}_{2} \mathrm{O}\right)_{2}$, in dry $\left[\mathrm{D}_{4}\right] \mathrm{MeOH}\left(\mathrm{CD}_{3} \mathrm{OD}\right.$, no water present) were obtained at different temperatures. Figure $5 \mathrm{~A}$ shows the signals for the $\mathrm{H}^{5}$ and $\mathrm{H}^{6}$ aromatic dmpp protons (6.0-8.0 ppm) from $25^{\circ} \mathrm{C}$ down to $-40{ }^{\circ} \mathrm{C}$, while Figure 5B shows the signals corresponding to the $\mathrm{H}^{5}(6.0$ $7.0 \mathrm{ppm}$ ) and $\mathrm{C}(2)-\mathrm{CH}_{3}(1.5-3.0 \mathrm{ppm}) \mathrm{dmpp}$ protons at $-50{ }^{\circ} \mathrm{C} \cdot{ }^{[14,19]}$ At $25^{\circ} \mathrm{C}$ (Figure 5A) two doublets are observed at $\delta=7.69 \mathrm{ppm}$ and $7.55 \mathrm{ppm}$, corresponding to the $\mathrm{H}^{6}$ protons of the $\mathrm{V}_{2} \mathrm{Y}_{2} \mathrm{~L}_{2}$ and $\mathrm{VYL}_{2}$ species, respectively, and a doublet at $\delta=6.55 \mathrm{ppm}$ and a broad signal at $\delta=$ $6.28 \mathrm{ppm}$, assigned to the $\mathrm{H}^{5}$ protons of the $\mathrm{V}_{2} \mathrm{Y}_{2} \mathrm{~L}_{2}$ and $\mathrm{VYL}_{2}$ species, respectively. These assignments were made taking into account the ${ }^{51} \mathrm{~V}$ NMR spectra previously discussed, which show the absence of the VYL and VL species when no water is present.

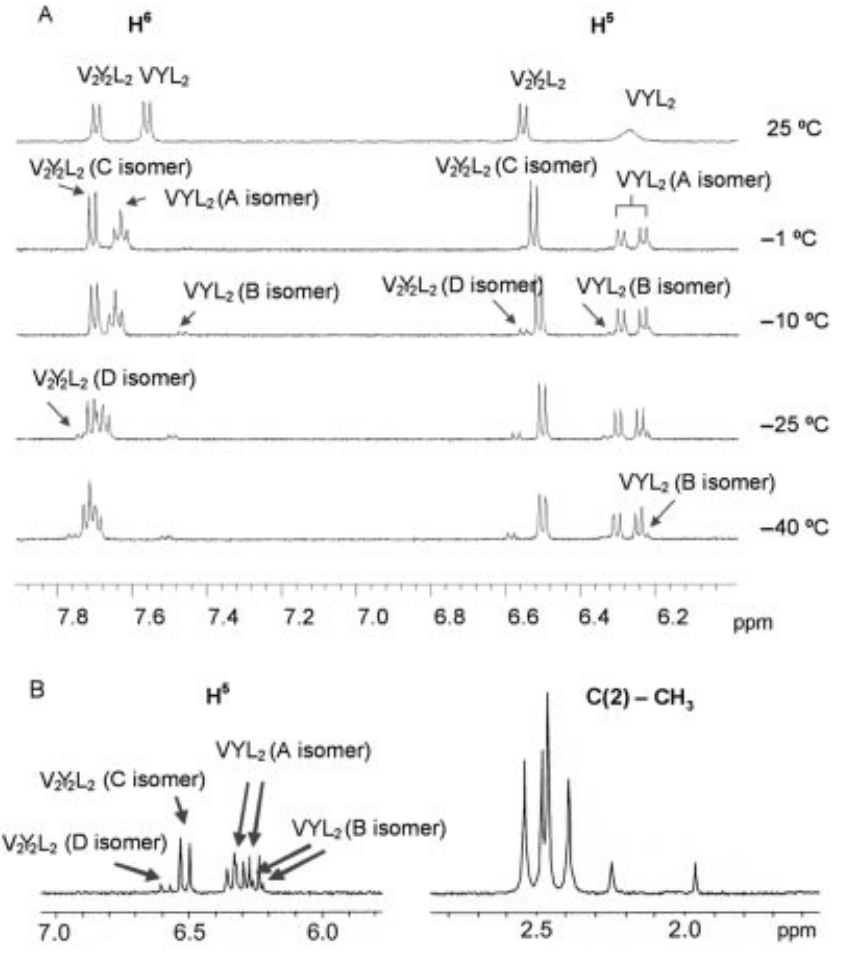

Figure 5. (A) $400 \mathrm{MHz}{ }^{1} \mathrm{H}$ NMR spectra of solutions of the crystalline $\mathrm{V}^{\mathrm{V}}$ compound $\left[\mathrm{V}_{3} \mathrm{O}_{6}(\mathrm{dmpp})_{3}\left(\mathrm{H}_{2} \mathrm{O}\right)\right] \cdot\left(\mathrm{H}_{2} \mathrm{O}\right)_{2}$ in $\mathrm{CD}_{3} \mathrm{OD}$, at different temperatures, showing only the signals corresponding to the $\mathrm{H}^{5}$ and $\mathrm{H}^{6}$ protons of the ligand dmpp; (B) $200 \mathrm{MHz}{ }^{1} \mathrm{H}$ NMR spectrum of a solution of the crystalline $\mathrm{V}^{\mathrm{V}}$ compound $\left[\mathrm{V}_{3} \mathrm{O}_{6}(\mathrm{dmpp})_{3}\left(\mathrm{H}_{2} \mathrm{O}\right)\right] \cdot\left(\mathrm{H}_{2} \mathrm{O}\right)_{2}$ in $\mathrm{CD}_{3} \mathrm{OD}$, at $-50^{\circ} \mathrm{C}$, showing only the signals corresponding to the $\mathrm{H}^{5}(6-7 \mathrm{ppm})$ and $\mathrm{C}(2)-\mathrm{CH}_{3}(1.5-$ $3 \mathrm{ppm}$ ) protons of the ligand dmpp. The assignments in the spectra of Figure 5A are made according to the structures of the isomers presented in Figure 6.

The ${ }^{1} \mathrm{H}$ NMR spectra at lower temperatures become more complex, revealing the presence of isomers of these complexes in solution. At $-1{ }^{\circ} \mathrm{C}$, the $6.28 \mathrm{ppm}\left(25^{\circ} \mathrm{C}\right)$ broad signal splits into two doublets at $\delta=6.32 \mathrm{ppm}$ and $6.25 \mathrm{ppm}$, while the $7.55 \mathrm{ppm}\left(25^{\circ} \mathrm{C}\right)$ signal originates from the triplet centred at $\delta=7.63 \mathrm{ppm}$ formed by two partially overlapping doublets (Figure $5 \mathrm{~A}, \mathrm{~b}$ ), which correspond to the nonequivalent $\mathrm{H}^{5}$ and $\mathrm{H}^{6}$ protons of the two ligands of the $\mathrm{VYL}_{2}$ compound. ${ }^{[14 a, 14 c, 19]}$ These features reflect the slowing down of the intramolecular dynamic processes, which, at higher temperature, average the two different environments of the $\mathrm{H}^{5}$ and $\mathrm{H}^{6}$ protons of the two ligands in the dominant cis isomer of $\mathrm{VYL}_{2}$ compound (isomer $\mathrm{A}$, Figure 6A), making them nonequivalent. At $-10^{\circ} \mathrm{C}$, the new low-intensity doublets appearing at $\delta=6.32 \mathrm{ppm}$ and $\delta=7.45 \mathrm{ppm}$ (Figure 5A) are indicative of the presence of isomeric forms, and correspond to the $\mathrm{H}^{5}$ and $\mathrm{H}^{6}$ protons of the less stable trans isomer of the $\mathrm{VYL}_{2}$ species (isomer $\mathrm{B}$, Figure 6B), respectively. The doublet at $\delta=6.56 \mathrm{ppm}$ with a weak intensity corresponds to the $\mathrm{H}^{5}$ proton of an isomer of the $\mathrm{V}_{2} \mathrm{Y}_{2} \mathrm{~L}_{2}$ dimer with the methoxy groups in a cis position (Figure 6D); this isomer is less stable than the major isomer with trans methoxy groups (Figure 6C), which is similar to the structure obtained in the crystal form. This 
A

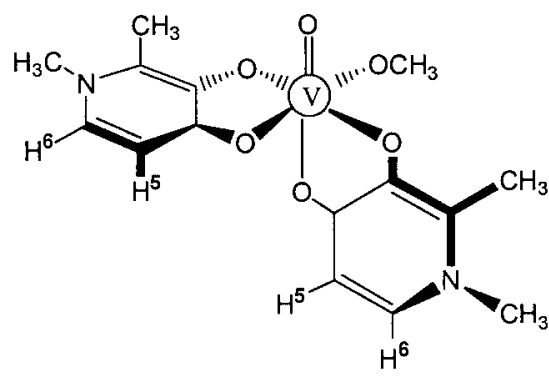

B

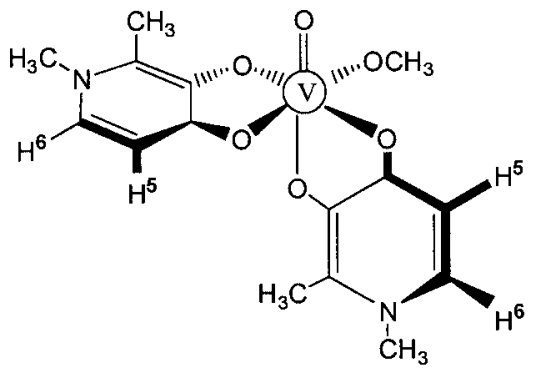

C

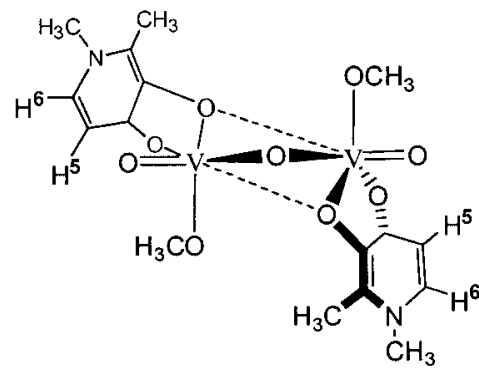

D

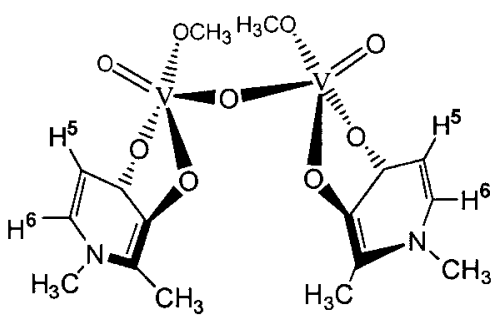

Figure 6. Schematic representation of the chemical structures of the possible isomers of: (A) the more stable and (B) the less stable isomers of the $\mathrm{VYL}_{2}$ species [VO(dmpp $\left.)_{2}(\mathrm{OMe})\right]$; and (C) the more stable and (D) the less stable isomers of the $\mathrm{V}_{2} \mathrm{Y}_{2} \mathrm{~L}_{2}$ species $\left[\mathrm{V}_{2} \mathrm{O}_{2}(\mu-\mathrm{O})\right.$ $\left.(\mathrm{dmpp})_{2}\left(\mathrm{OCH}_{3}\right)_{2}\right]$, in methanol solution.

doublet is shifted to $6.57 \mathrm{ppm}$ at $-25^{\circ} \mathrm{C}$ and to $6.58 \mathrm{ppm}$ at $-40{ }^{\circ} \mathrm{C}$ (Figure $5 \mathrm{~A}$ ). At $-10^{\circ} \mathrm{C}$ the $\mathrm{H}^{6}$ signal of this isomer is not observed, as it overlaps with the large $\mathrm{H}^{6}$ signal of the major $\mathrm{V}_{2} \mathrm{Y}_{2} \mathrm{~L}$ isomer. However, at $-25^{\circ} \mathrm{C}$ it can be seen at $\delta=7.75 \mathrm{ppm}$ and it shifts to $7.76 \mathrm{ppm}$ at $-40{ }^{\circ} \mathrm{C}$. At lower temperatures the signals of the $\mathrm{H}^{6}$ proton of the two isomers of $\mathrm{VYL}_{2}$ are shifted to higher frequencies- the signal of the major isomer (isomer A) becomes superimposed with the $\mathrm{H}^{6}$ proton signals of the $\mathrm{V}_{2} \mathrm{Y}_{2} \mathrm{~L}_{2}$ compound.

A schematic representation of the proposed chemical structures of the two isomers for each of these two species, which is in agreement with the NMR spectroscopic data, is presented in Figure 6. From the ${ }^{1} \mathrm{H}$ NMR spectroscopic data, it is expected that the two $\mathrm{H}^{6}$ protons of the dmpp ligands in the $\mathrm{V}_{2} \mathrm{Y}_{2} \mathrm{~L}_{2}$ compound are equivalent in each isomer; the same can be said for the two $\mathrm{H}^{5}$ protons (Figure $6 \mathrm{C}$ and $\mathrm{D})$. These protons in the $\mathrm{VYL}_{2}$ species are nonequivalent in both isomers (Figure 6A and B), although they are indistinguishable at $25^{\circ} \mathrm{C}$ (Figure 5A) because of the presence of intramolecular averaging processes that are fast on the NMR time-scale. The structures $\mathrm{A}$ and $\mathrm{C}$ of Figure 6 are assumed to represent the more stable isomers of $\mathrm{VYL}_{2}$ and $\mathrm{V}_{2} \mathrm{Y}_{2} \mathrm{~L}_{2}$, respectively. This assumption is based on the present $\mathrm{X}$-ray crystal structure data for $\mathrm{V}_{2} \mathrm{~L}_{2}$ and on the literature data for $\mathrm{VYL}_{2}(\mathrm{~L}=\mathrm{ma}) .{ }^{[14,15]}$ However, a more precise knowledge of the relative stability of the structures in solution would require a study involving theoretical energy calculations.

Figure 5B presents an ${ }^{1} \mathrm{H}$ NMR spectrum obtained at $-50{ }^{\circ} \mathrm{C}$ that shows the spectral regions $5.8-7.0 \mathrm{ppm}$, corresponding to the $\mathrm{H}^{5}$ protons, and $1.5-3.0 \mathrm{ppm}$, correspond- ing to the protons of the $\mathrm{CH}_{3}$ group attached to the $\mathrm{C}(2)$ atom of the dmpp molecule. The different doublets corresponding to the $\mathrm{H}^{5}$ protons in the different species in solution are better resolved and corroborate the presence of two isomers for the $\mathrm{V}_{2} \mathrm{Y}_{2} \mathrm{~L}_{2}$ complex (one doublet at $\delta=$ $6.51 \mathrm{ppm}$ for the more stable isomer $\mathrm{C}$ and one doublet at $\delta=6.59 \mathrm{ppm}$ for the less stable isomer D) and two isomers of the $\mathrm{VYL}_{2}$ compound (two doublets at $\delta=6.24 \mathrm{ppm}$ and $6.35 \mathrm{ppm}$ for the less stable isomer B and two doublets at $\delta$ $=6.25 \mathrm{ppm}$ and $6.31 \mathrm{ppm}$ for the more stable isomer A). With respect to the protons of the $\mathrm{C}(2)-\mathrm{CH}_{3}$ group, six singlets are observed: two signals are assigned to the $\mathrm{CH}_{3}$ protons of the two isomers of the $\mathrm{V}_{2} \mathrm{Y}_{2} \mathrm{~L}_{2}$ complex, each one corresponding to the six protons of the two equivalent $\mathrm{CH}_{3}$ groups of each isomer, and the other four signals correspond to the four $\mathrm{CH}_{3}$ groups (two nonequivalent $\mathrm{CH}_{3}$ groups in each isomer of the $\mathrm{VYL}_{2}$ complex).

\section{D NMR Spectroscopic Experiments}

Two-dimensional (2D) ${ }^{1} \mathrm{H}$ NMR experiments, COSY $(J$ correlated spectroscopy) and EXSY [exchange correlated spectroscopy, obtained using a phase-sensitive nuclear Overhauser spectroscopy (NOESY) pulse sequence], were carried out to further investigate the existence of different isomeric forms in solution, complementing the data obtained through one-dimensional (1D) ${ }^{1} \mathrm{H}$ NMR spectra at low temperature $\left(-1{ }^{\circ} \mathrm{C}\right.$ to $\left.-50{ }^{\circ} \mathrm{C}\right)$.

Figure 7 shows the low field region $(6.0-8.0 \mathrm{ppm})$ of the 2D-COSY (Figure 7A) and 2D-EXSY (Figure 7B) spectra at $-10^{\circ} \mathrm{C}$. This temperature value and the region in which the $\mathrm{H}^{5}$ and $\mathrm{H}^{6}$ signals of the dmpp ligand appear proved to 


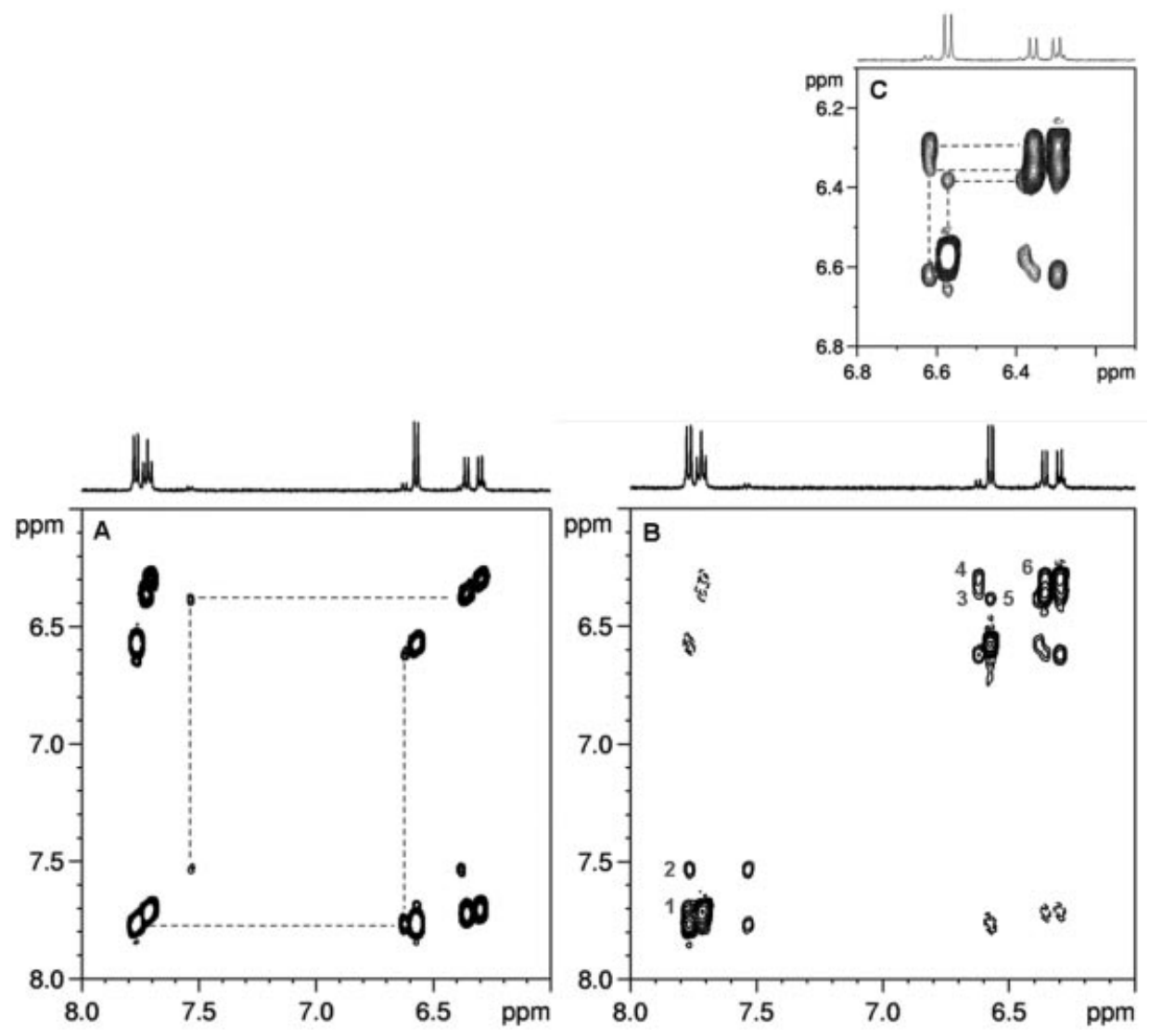

Figure 7. $400 \mathrm{MHz} 2 \mathrm{D}{ }^{1} \mathrm{H}$ homonuclear $\mathrm{NMR}$ spectra (spectral region 6-8 ppm) of solutions containing the $\mathrm{V}^{\mathrm{V}}$ compound $\left[\mathrm{V}_{3} \mathrm{O}_{6}\right.$ (dmpp) $\left.)_{3}\left(\mathrm{H}_{2} \mathrm{O}\right)\right]^{\circ}\left(\mathrm{H}_{2} \mathrm{O}\right)_{2}$, in $\mathrm{CD}_{3} \mathrm{OD}$, at $-10^{\circ} \mathrm{C}$ : (A) COSY spectrum; and (B) EXSY spectrum (mixing time $800 \mathrm{~ms}$ ) with $(\mathrm{C})$ an expansion of the $\mathrm{H}^{5}$ proton region. The contours of positive and negative peaks are defined by continuous and dashed lines, respectively.

give the most relevant information. In the COSY spectrum, cross-peaks correlating the protons $\mathrm{H}^{5}$ and $\mathrm{H}^{6}$ of each species in solution are expected. One cross-peak for each of the isomers $\mathrm{C}$ and $\mathrm{D}$ of $\mathrm{V}_{2} \mathrm{Y}_{2} \mathrm{~L}_{2}$, two cross-peaks for the two ligands of the major isomer of $\mathrm{VYL}_{2}$ (isomer $\mathrm{A}$ ) and only one of the two expected for its minor isomer (isomer B) can be observed. These observations confirm the assignments described above for the $1 \mathrm{D}{ }^{1} \mathrm{H}$ NMR spectra.

The phase sensitive 2D-EXSY spectrum in the pure double absorption mode contains two types of cross-peaks. For small molecules, like those studied here, the cross-peaks resulting from nuclear Overhauser effects (nOes) that are based on the intramolecular dipolar interactions of protons $\mathrm{H}^{5}$ and $\mathrm{H}^{6}$ of the same ligand, which are close in space, have negative intensities and appear at the same positions as the COSY cross-peaks. Only three nOe cross-peaks are observed, two for the major isomer (A) of $\mathrm{VL}_{2}$ and one for the major isomer (C) of $\mathrm{V}_{2} \mathrm{Y}_{2} \mathrm{~L}_{2}$, as those for the minor isomers could not be detected. The diagonal peaks and the exchange cross-peaks resulting from the exchange processes that occur between different species and/or between the isomeric forms of a given species have positive intensities. The exchange cross-peaks observed for mixing times $\tau_{\mathrm{m}}>1 / R$, where $R=k_{\mathrm{ex}} / \Delta v_{\mathrm{o}}$ is the ratio of the exchange rate constant and the chemical shift difference between the exchanging peaks of the same proton in the two species, give useful information about the dynamic equilibria in solution. ${ }^{[31]}$ Their intensities are related to the corresponding exchange rate constants of the exchange equilibrium. A qualitative analysis of the exchange patterns of Figure 7B shows six cross-peaks, two in the $\mathrm{H}^{5}$ region and four in the $\mathrm{H}^{6}$ region. In the $\mathrm{H}^{5}$ region, there are two stronger correlations - one between the two ligands of the major isomer of $\mathrm{VYL}_{2}$ (A) and one between the minor isomer of $\mathrm{V}_{2} \mathrm{Y}_{2} \mathrm{~L}_{2}$ (D) and one of the two $\mathrm{H}^{5}$ protons of the major isomer of $\mathrm{VYL}_{2}$ (A). Two weaker correlations in the $\mathrm{H}^{5}$ region are observed between the minor isomer of $\mathrm{V}_{2} \mathrm{Y}_{2} \mathrm{~L}_{2}$ (D) and the other $\mathrm{H}^{5}$ protons of the major isomer of $\mathrm{VL}_{2}(\mathrm{~A})$, and between the major isomer of $\mathrm{V}_{2} \mathrm{Y}_{2} \mathrm{~L}_{2}(\mathrm{C})$ and the minor isomer of $\mathrm{VYL}_{2}$ (B). In the $\mathrm{H}^{6}$ region, two weak cross-peaks are observed one involving correlation of the major or minor isomers of $\mathrm{V}_{2} \mathrm{Y}_{2} \mathrm{~L}_{2}\left(\mathrm{C}\right.$ or D) with the major isomer of $\mathrm{VYL}_{2}(\mathrm{~A})$ and the other with its minor isomer (B). This uncertainty results from the overlap of the $\mathrm{H}^{6}$ resonances of isomers $\mathrm{C}$ and $\mathrm{D}$ of $\mathrm{V}_{2} \mathrm{Y}_{2} \mathrm{~L}_{2}$. However, taking into account the exchange pattern observed for the $\mathrm{H}^{5}$ protons, the $\mathrm{A} \leftrightarrow \mathrm{D}$ and $\mathrm{B} \leftrightarrow \mathrm{C}$ correlations between the $\mathrm{H}^{6}$ protons are more plausible. There is no evidence of cross-peaks correlating the $\mathrm{H}^{5}$ or $\mathrm{H}^{6}$ protons of the two isomers of the same species.

In conclusion, the ${ }^{51} \mathrm{~V}$ NMR spectroscopic data show that two different oligomeric species containing $\mathrm{V}^{\mathrm{V}}$ and $\mathrm{dmpp}$ can be isolated in water and methanol. Their X-ray 
crystal structures show that the water species is a cyclic $\mathrm{V}_{3} \mathrm{~L}_{3}$ trimer, $\left[\mathrm{V}_{3} \mathrm{O}_{3}(\mu-\mathrm{O})_{3}(\mathrm{dmpp})_{3}\left(\mathrm{H}_{2} \mathrm{O}\right)\right]\left(\mathrm{H}_{2} \mathrm{O}\right)_{2}$, while the methanol species is a $\mathrm{V}_{2} \mathrm{Y}_{2} \mathrm{~L}_{2}$ dimer, $\left[\mathrm{V}_{2} \mathrm{O}_{2}(\mu-\mathrm{O})(\mathrm{dmpp})_{2^{-}}\right.$ $\left(\mathrm{OCH}_{3}\right)_{2}$ ]. Dissolution of black crystals of the $\mathrm{V}_{3} \mathrm{~L}_{3}$ trimer in methanol leads to its complete dissociation into a $\mathrm{V}_{2} \mathrm{Y}_{2} \mathrm{~L}_{2}$ dimer, a $\mathrm{VYL}_{2}$ monomer and monovanadate, each of which has one methoxy group coordinated to the $\mathrm{V}^{\mathrm{V}}$ atoms. Red crystals of the dimer were isolated from the methanol solution. Increasing the amount of water in mixtures with methanol leads successively to the appearance of $\mathrm{VL}$, the disappearance of $\mathrm{V}_{2} \mathrm{Y}_{2} \mathrm{~L}_{2}$ and the monomer species, while the trimer dominates at high water content.

On the basis of the results from the 2D-EXSY NMR experiments, the following intermolecular exchange equilibria between the different species were detected in a $\mathrm{CD}_{3} \mathrm{OD}$ solution of the trimer $\mathrm{V}^{\mathrm{V}}$ complex:

$\mathrm{V}_{2} \mathrm{Y}_{2} \mathrm{~L}_{2}(\mathrm{C}$ isomer $) \leftrightarrows \mathrm{VYL}_{2}$ (B isomer)

$\mathrm{V}_{2} \mathrm{Y}_{2} \mathrm{~L}_{2}$ (D isomer) $\leftrightarrows \mathrm{VYL}_{2}$ (A isomer)

These equilibria involve exchange between the major isomer and the minor isomer of species of different nuclearity. Intramolecular exchange was also detected between the two ligands of $\mathrm{VYL}_{2}$ (isomer $\mathrm{A}$ ), but no evidence was found for intermolecular exchange between the major and minor isomers of species of different nuclearity or between isomers of species of the same nuclearity.

\section{Experimental Section}

Reagents: Sodium metavanadate, $\mathrm{NaVO}_{3}$, and methanol were purchased from Sigma, and the ligand 1,2-dimethyl-3-hydroxy-4-pyridinone (Hdmpp) from ACROS Organics and used without further purification. $\mathrm{KOH}, \mathrm{HCl}$ and $\mathrm{CH}_{3} \mathrm{OH}$ were obtained from Merck, while $\mathrm{KOD}, \mathrm{DCl}, \mathrm{D}_{2} \mathrm{O}\left(99.9\right.$ atom \% D) and $\mathrm{CD}_{3} \mathrm{OD}$ (99.9 atom \% D) from Cambridge Isotope Laboratories. All the experiments were carried out under aerobic conditions.

Synthesis: The synthesis of the trimer $\left[\mathrm{V}_{3} \mathrm{O}_{3}(\mu-\mathrm{O})_{3}(\mathrm{dmpp})_{3^{-}}\right.$ $\left.\left(\mathrm{H}_{2} \mathrm{O}\right)\right]\left(\mathrm{H}_{2} \mathrm{O}\right)_{2}$ was carried out following the procedure described in the literature. ${ }^{[24]}$ Red crystals of $\left[\mathrm{V}_{2} \mathrm{O}_{2}(\mu-\mathrm{O})(\mathrm{dmpp})_{2}\left(\mathrm{OCH}_{3}\right)_{2}\right]$ were isolated from methanolic solution of the trimer; however, under atmospheric conditions these crystals turn black after replacement of methanol by water.

Solutions: Solutions of the trimer $\left[\mathrm{V}_{3} \mathrm{O}_{3}(\mu-\mathrm{O})_{3}(\mathrm{dmpp})_{3}\left(\mathrm{H}_{2} \mathrm{O}\right)\right]$ $\left(\mathrm{H}_{2} \mathrm{O}\right)_{2}$ used for the ${ }^{51} \mathrm{~V}$ NMR spectroscopic experiments contained $\mathrm{CH}_{3} \mathrm{OH}$ or $\mathrm{CH}_{3} \mathrm{OH} / \mathrm{H}_{2} \mathrm{O}$ mixtures, and were prepared by dissolving the appropriate amount of the solid compound in the solvent (or solvents) in order to have the desired concentrations. The $\mathrm{CH}_{3} \mathrm{OH} / \mathrm{H}_{2} \mathrm{O}$ mol ratios were checked by integration of the ${ }^{1} \mathrm{H}$ NMR signals of the solvents. 1D ${ }^{1} \mathrm{H}$ NMR spectra as well as $2 \mathrm{D}$ ${ }^{1} \mathrm{H}$ COSY and EXSY NMR spectra were acquired in $\mathrm{CD}_{3} \mathrm{OD}$ solutions. $\mathrm{pH}$ values were measured by using a Crison MicropH 2002 $\mathrm{pH}$ meter with an Ingold 405-M5 combined electrode.

\section{Methods}

NMR Spectroscopy: ${ }^{51} \mathrm{~V}$ NMR spectra at $22.0 \pm 0.5^{\circ} \mathrm{C}$ were recorded with a Varian Unity-500 Spectrometer operating at 131.404 MHz, using a $5 \mathrm{~mm}$ broad band probe. ${ }^{51} \mathrm{~V}$ NMR chemical shifts were externally referenced to a $\mathrm{VOCl}_{3}$ solution at $0 \mathrm{ppm}$. The ${ }^{51} \mathrm{~V}$ NMR acquisition parameters were: $33 \mathrm{kHz}$ spectral width, $25 \mu$ s pulse width, $0.5 \mathrm{~s}$ acquisition time and $10 \mathrm{~Hz}$ line broadening.

${ }^{1} \mathrm{H}$ NMR spectra were obtained by using a pre-saturation pulse sequence to eliminate the residual water signal. The low-temperature $1 \mathrm{D}$ and the $2 \mathrm{D}{ }^{1} \mathrm{H}$ NMR spectra were obtained with a Bruker ARX400 NMR Spectrometer operating at $400.13 \mathrm{MHz}$, using a $5 \mathrm{~mm}$ inverse probe and a controlled-temperature unit. Magnitude COSY and phase sensitive NOESY (800 ms mixing time) were acquired with a spectral width of $4000 \mathrm{~Hz}$ in both F1 and F2, with $1024 \times 256$ data points. Spectra were processed with unshifted sine bell (COSY) and sine ${ }^{2}$ (NOESY) functions. The ${ }^{1} \mathrm{H}$ NMR spectrum at $-50{ }^{\circ} \mathrm{C}$ was obtained with a Bruker AC $200 \mathrm{~F}$ Spectrometer operating at $200.13 \mathrm{MHz}$, using a $5-\mathrm{mm}$ probe and a controlledtemperature unit.

ES Mass Spectrum: Electron spray (ES) mass spectra were recorded with an MSD spectrometer with a fragmentation of $50 \mathrm{~V}$ in a mixture of $98 \%$ methanol $/ 2 \%$ formic acid: $m / z=457\left[\mathrm{~V}_{2} \mathrm{O}_{3}-\right.$ $\left.\left(\mathrm{C}_{7} \mathrm{H}_{8} \mathrm{O}_{2} \mathrm{~N}\right)_{2}\left(\mathrm{OCH}_{3}\right)\right]^{+}, \quad 343 \quad\left[\mathrm{VO}\left(\mathrm{C}_{7} \mathrm{H}_{8} \mathrm{O}_{2} \mathrm{~N}\right)_{2}\right]^{+}, \quad 236 \quad[\mathrm{VO}-$ $\left.\left(\mathrm{C}_{7} \mathrm{H}_{8} \mathrm{O}_{2} \mathrm{~N}\right)\left(\mathrm{OCH}_{3}\right)\right]^{+}$.

X-ray Crystallography: The crystalline trimer $\left[\mathrm{V}_{3} \mathrm{O}_{3}(\mu-\mathrm{O})_{3}(\mathrm{dmpp})_{3^{-}}\right.$ $\left.\left(\mathrm{H}_{2} \mathrm{O}\right)\right]\left(\mathrm{H}_{2} \mathrm{O}\right)_{2}$ was dissolved in methanol until saturation was reached. After a few hours, slow evaporation of this solution gave dark red crystals of X-ray quality. A suitable crystal of $\left[\mathrm{V}_{2} \mathrm{O}_{2}(\mu\right.$ $\left.\mathrm{O})(\mathrm{dmpp})_{2}\left(\mathrm{OCH}_{3}\right)_{2}\right]$ was coated with Fomblin oil, placed at the end of a silica fibre and mounted on a goniometer head of a Bruker SMART CCD diffractometer in a stream of cold nitrogen gas. These crystals are unstable and turn black when left in contact with atmospheric conditions.

Selected crystallographic data are shown in Table 2. Three-dimensional X-ray data were collected at low temperature $(173 \mathrm{~K})$ in the range $1.90<2 \theta<28.32^{\circ}$ with a Siemens SMART 1000 CCD diffractometer by the $\Omega$-scan method. Complex scattering factors were taken from the programme package SHELXTL. ${ }^{[32]}$ The structure was solved by direct methods and refined by using full-matrix leastsquares methods on $F^{2}$. The data were processed and corrected for Lorentz and polarisation effects and for absorption (semi-empirical method). The non-hydrogen atoms were refined with anisotropic thermal parameters in all cases. The hydrogen atoms were refined to carbon, which were placed in idealised positions and refined by using a riding mode. A final difference Fourier map showed no residual density outside -1.064 to $+0.845 \mathrm{e}^{-3}$. Selected bond lengths and bond angles appear in Table 1.

Table 2. Crystallographic data for the complex $\left[\mathrm{V}_{2} \mathrm{O}_{2}(\mu-\mathrm{O})-\right.$ $\left.(\mathrm{dmpp})_{2}\left(\mathrm{OCH}_{3}\right)_{2}\right]$.

Empirical formula

Formula mass $\left[\mathrm{g} \mathrm{mol}^{-1}\right]$

Crystal system

Space group

$a[\AA]$

$b[\AA]$

$c[\AA]$

$\beta\left[{ }^{\circ}\right]$

$V\left[\AA^{3}\right]$

$\mathrm{Z}$

$T[\mathrm{~K}]$

$\lambda[\AA]$

$D_{\text {calcd. }}\left[\mathrm{g} \cdot \mathrm{cm}^{-3}\right]$

$F(000)$

No. of reflections collected

No. of observed reflections

$R_{1}{ }^{\text {[a] }}$

$w R_{2}$ (all data)

Largest diff peak and hole [e $\AA^{-3}$ ]

[a] $R_{1}=\Sigma|| F_{\mathrm{o}}|-| F_{\mathrm{c}} \| / \Sigma\left|F_{\mathrm{o}}\right|, w R_{2}=\left\{\Sigma\left[w\left(\left.|| F_{\mathrm{o}}\right|^{2}-\left|F_{\mathrm{c}}\right|^{2} \mid\right)^{2}\right] / \Sigma\left[w\left(F_{\mathrm{o}}{ }^{4}\right)\right]\right\}^{1 / 2}$. $\mathrm{C}_{16} \mathrm{H}_{22} \mathrm{~N}_{2} \mathrm{O}_{9} \mathrm{~V}_{2}$ 488.24 monoclinic $P 2_{1} / c$ 8.4573(11) $15.034(2)$ $15.849(2)$ $105.300(2)$ 1943.7(4) 2 $173(2)$ 0.71073 1.668 1000 10939 3038 0.0492 0.1706 $0.845 /-1.064$ 3593 
CCDC-602237 contains the supplementary crystallographic data for this paper. These data can be obtained free of charge from The Cambridge Crystallographic Data Centre via www.ccdc.cam.ac.uk/ data_request/cif.

\section{Acknowledgments}

We are grateful for the financial support from Fundação para a Ciência e Tecnologia, Portugal (FCT Project POCTI/QUI//56949/ 2004) and FEDER. F. A. thanks Xunta de Galicia and the University of A Coruña for the grants to visit the University of Coimbra and the Spanish-Portuguese Bilateral Programme (Accion Integrada HP2004-0074). This work was carried out within the working group "Vanadium Compounds as Insulin-Mimetic Agents" of the COST D21 Action of the E. U.

[1] N. D. Chasteen (Ed.), Vanadium in Biological Systems, Kluwer, Dordrecht, The Netherlands, 1990.

[2] H. Sigel, A. Sigel (Eds.), Metal Ions in Biological Systems, Marcel Dekker, Inc., New York, 1995, vol. 31.

[3] E. M. Armstrong, R. L. Beddoes, L. J. Calviou, J. M. Charnock, D. Collison, N. Ertok, J. H. Naismith, C. D. Garner, J. Am. Chem. Soc. 1993, 115, 807-808.

[4] a) M. J. Smith, Experiencia 1989, 45, 452; b) S. W. Taylor, B. Kammerer, E. Bayer, Chem. Rev. 1997, 97, 333-346.

[5] H. Vilter, Phytochemistry 1984, 23, 1387-1390.

[6] a) R. L. Robson, R. R. Eady, T. H. Richardson, R. W. Miller, M. Hawkins, J. R. Postgate, Nature (London) 1986, 322, 388390; b) D. Rehder, Coord. Chem. Rev. 1999, 182, 297-322; c) R. R. Eady, Coord. Chem. Rev. 2003, 237, 23-30.

[7] a) P. J. Stankiewicz, A. S. Tracey and D. C. Crans, "Vanadium and its Role in Life" in Metal Ions in Biological Systems (Eds.: H. Sigel, A. Sigel), Marcel Dekker, New York, 1995, vol. 31, ch. 9; b) A. B. Goldfine, G. Willksy, C. R. Kahn in Vanadium Compounds: Biochemistry Chemistry, and Therapeutic Applications (Eds.: A. S. Tracey, D. C. Crans), American Chemical Society, Washington, DC, 1998.

[8] N. D. Chasteen, "The Biochemistry of Vanadium" in Structure and Bonding 1983, 53, 105-138.

[9] a) Y. Shechter, S. J. D. Karlish, Nature 1980, 284, 556-558; b) H. Sakurai, K. Tsuchiya, M. Nukatsuka, M. Sofue, J. Kawada, J. Endocrinol. 1990, 126, 451-459; c) K. Kawabe, M. Tadokoro, Y. Kojima, Y. Fujisawa, H. Sakurai, Chem. Lett. 1998, 9-10.

[10] a) D. C. Crans, L. Yang, J. A. Alfano, L.-H. Chi, W. Jin, M. Mahroof-Tahir, K. Robbins, M. M. Toloue, L. K. Chan, A. J. Plante, R. Z. Grayson, G. R. Willsky, Coord. Chem. Rev. 2003, 237, 13-22; b) H. Sakurai, H. Yasui, Y Adachi, Expert Opin. Invest. Drugs 2003, 12, 1189-1203.

[11] D. Rehder, Angew. Chem. Int. Ed. Engl. 1991, 30, 148-167.

[12] a) M. J. Gresser, A. S. Tracey, J. Am. Chem. Soc. 1986, 108, 1935-1939; b) A. S. Tracey, M. J. Gresser, Can. J. Chem. 1988, 66, 2570-2574; c) A. S. Tracey, M. J. Gresser, B. Galeffi, Inorg. Chem. 1988, 27, 157-161.

[13] D. C. Crans, J. J. Smee, E. Gaidamauskas, L. Yang, Chem. Rev. 2004, 104, 849-902.

[14] a) P. Caravan, L. Gelmini, N. Glover, F. G. Herring, H. Li, J. H. McNeill, S. J. Rettig, I. A. Setyawati, E. Shuter, Y. Sun, A. S. Tracey, V. G. Yuen, C. Orvig, J. Am. Chem. Soc. 1995, 117 , 12759-12770; b) J. H. McNeil, V. G. Yuen, H. R. Hoveyda, C. Orvig, J. Med. Chem. 1992, 35, 1489-1491; c) G. R. Hanson, Y. Sun, C. Orvig, Inorg. Chem. 1996, 35, 6507-6512.

[15] a) Y. Sun, B. R. James, S. J. Rettig, C. Orvig, Inorg. Chem. 1996, 35, 1667-1673; b) Y. Sun, M. Melchior, D. A. Summers, R. C. Thompson, S. J. Rettig, C. Orvig, Inorg. Chem. 1998, 37, 3119-3121.
[16] J. Burgess, B. de Castro, C. Oliveira, M. Rangel, W. Schlindwein, Polyhedron 1997, 16, 789-794.

[17] a) M. M. C. A. Castro, C. F. G. C. Geraldes, P. Gameiro, E. Pereira, B. Castro, M. Rangel, J. Inorg. Biochem. 2000, 80, 177179; b) M. Rangel, Transition Met. Chem. 2001, 26, 219-223.

[18] a) M. M. C. A. Castro, F. Avecilla, C. F. G. C. Geraldes, B. de Castro, M. Rangel, Inorg. Chim. Acta 2003, 356, 142-154; b) P. Buglyo, T. Kiss, E. Kiss, D. Sanna, E. Garriba, G. Micera, J. Chem. Soc., Dalton Trans. 2002, 2275-2282.

[19] A. Katoh, K. Kazutoshi, R. Saito, Y. Fujisawa, T. Takino, H. Sakurai, Heterocycles 2003, 60, 1147-1159.

[20] K. H. Thompson, B. D. Liboiron, Y. Sun, K. D. D. Bellman, I. A. Setyawati, B. O. Patrick, V. Karunaratne, G. Rawji, J. Wheeler, K. Sutton, S. Bhanot, C. Cassidy, J. H. McNeill, V. G. Yuen, C. Orvig, J. Biol. Inorg. Chem. 2003, 8, 66-74.

[21] a) P. Poucheret, R. Gross, A. Cadene, M. Manteguetti, J. Serrano, G. Ribes, G. Cross, Mol. Cell. Biochem. 1995, 153, 197204; b) H. Sakurai, K. Fujii, H. Watanabe, H. Tamura, Biochem. Biophys. Res. Commun. 1995, 214, 1095-1101; c) H. Sakurai, K. Tsuchiya, M. Nukatsuka, J. Kawada, S. Ischikawa, H. Yoshida, M. Komatsu, J. Clin. Biochem. Nutr. 1990, 8, 193200; d) H. Watanabe, M. Nakai, K. Komazawa, H. Sakurai, J. Med. Chem. 1994, 37, 876-877; e) J. H. McNeill, V. G. Yuen, S. Dai, C. Orvig, Mol. Cell. Biochem. 1995, 153, 175-180; f) H. Sakurai, K. Fujii, S. Fujimoto, Y. Fujisawa, K. Takechi and H. Yasui in ACS Symposium Series 711 (Ed.: A. S. Tracey and D. C. Crans), American Chemical Society, Washington D.C., 1998, p. 344; g) H. Sakurai, Y. Fujisawa, S. Fujimoto, H. Yasui, T. Takino, J. Trace Elem. Exp. Med. 1999, 12, 393-401.

[22] T. C. Delgado, A. I. Tomaz, I. Correia, J. C. Pessoa, J. G. Jones, C. F. G. C. Geraldes, M. M. C. A. Castro, J. Inorg. Biochem. 2005, 99, 2328-2339.

[23] a) D. Rehder, J. C. Pessoa, C. F. G. C. Geraldes, M. M. C. A. Castro, T. Kabanos, T. Kiss, B. Maier, G. Micera, L. Petterson, M. Rangel, A. Salifoglou, I. Turel, D. Wang, J. Biol. Inorg. Chem. 2002, 7, 384-396; b) M. Rangel, A. Tamura, C. Fukushima, H. Sakurai, J. Biol. Inorg. Chem. 2001, 6, 128-132.

[24] F. Avecilla, C. F. G. C. Geraldes, M. M. C. A. Castro, Eur. J. Inorg. Chem. 2001, 3135-3142.

[25] F. Jiang, P. A. Oren, S. M. Miller, J. Chen, M. Mahroof-Tahir, D. C. Crans, Inorg. Chem. 1998, 37, 5439-5451.

[26] a) K. Isobe, S. I. Ooi, Y. Nakamura, S. Kawaguchi, H. Kuroya, Chem. Lett. 1975, 35-38; b) C. R. Cornman, J. Kampf, M. S. Lah, V. L. Pecoraro, Inorg. Chem. 1992, 31, 2035-2043; c) X. Li, M. S. Lah, V. L. Pecoraro, Inorg. Chem. 1988, 27, 46574664.

[27] S. A. Fairhust, D. L. Hughes, U. Kleinkes, J. G. Leigh, J. R. Sanders, J. Weisner, J. Chem. Soc., Dalton Trans. 1995, 321326.

[28] C. J. Carrano, C. M. Nunn, R. Quan, J. A. Bonadies, V. L. Pecoraro, Inorg. Chem. 1990, 29, 944-951.

[29] a) I. Cavaco, J. Costa-Pessoa, M. T. Duarte, P. M. Matias, R. T. Henriques, Polyhedron 1993, 12, 1231-1237; b) W. Priebsch, D. Rehder, M. von Oeynhausen, Chem. Ber. 1991, 124, 761-764; c) H. Rieskamp, P. Gietz, R. Mattes, Chem. Ber. 1976, 109, 2090-2096.

[30] a) D. Paulsen, D. Rehder, D. Thoennes, Z. Naturforsch., Teil A 1978, 33, 834-839; b) D. Rehder, Bull. Magn. Reson. 1982, 4, 33-83; c) A. S. Tracey, M. Gresser, K. M. Parkinson, Inorg. Chem. 1987, 26, 629-638.

[31] a) G. Otting, E. Liepinsh, K. Wüthrich, J. Am. Chem. Soc. 1990,113, 4363-4364; b) D. Neuhaus, M. Williamson (Eds.), "The Nuclear Overhauser Effect" in Structural and Conformational Analysis, $2^{\text {nd }}$ ed., Wiley-VCH Inc., Chichester, United Kingdom, 2000.

[32] G. M. Sheldrick, SHELXTL Bruker Analytical X-ray System, ver. 5.01, Madison, WI, 1997.

Received: April 4, 2006 Published Online: July 24, 2006 